\title{
ACAT2 Promotes Cell Proliferation and Associates with Malignant Progression in Colorectal Cancer [Corrigendum]
}

Weng M, Zhang H, Hou W, Sun Z, Zhong J, Miao C. Onco Targets Ther. 2020;13:3477-3488.

The authors have advised Figures $4 \mathrm{~A}$ and $5 \mathrm{~K}$ are incorrect. The correct Figures 4 and 5 are shown below.
The authors apologize for these errors and advise that this does not affect the results of the paper.

A
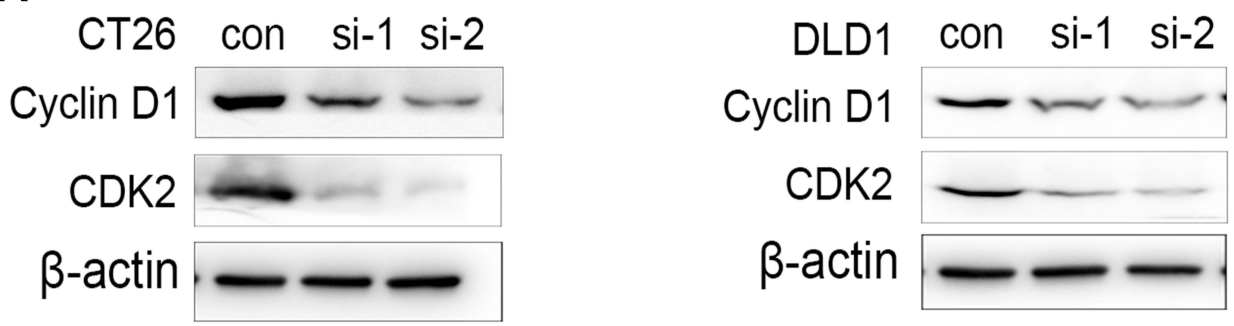

B

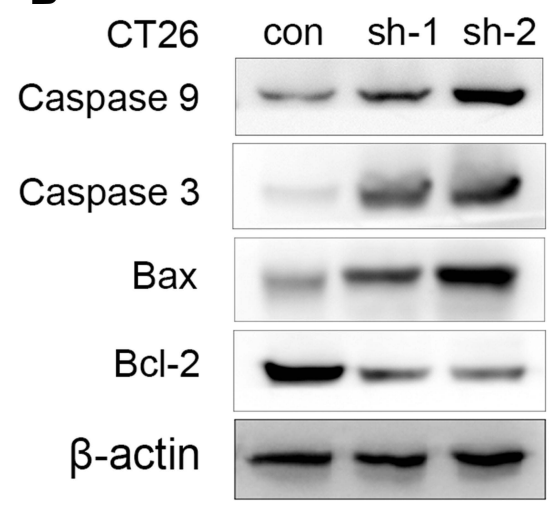

DLD1 con sh-1 sh-2

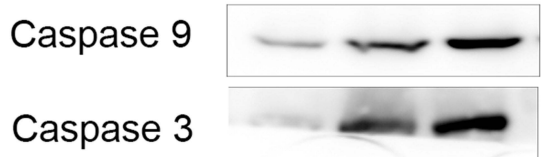

Bax

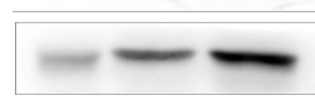

$\mathrm{Bcl}-2$

$\beta$-actin

Figure 4 The regulation of some apoptotic marker in CT26 and DLDI cells by ACAT2 knockdown. (A) The expression of cyclin DI and CDK2 in CT26 or CT26 cells transfected with siRNA-ACAT2 (DLDI or DLDI cells transfected with siRNA-ACAT2). (B) The expression of caspase 3, caspase 9 , Bcl-2 and Bax in CT26 or CT26 cells transfected with siRNA-ACAT2 (DLDI or DLDI cells transfected with siRNA-ACAT2). 
A

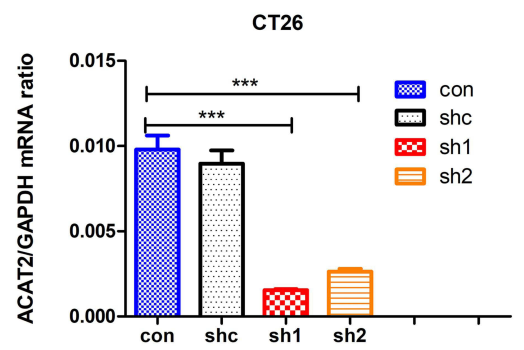

D

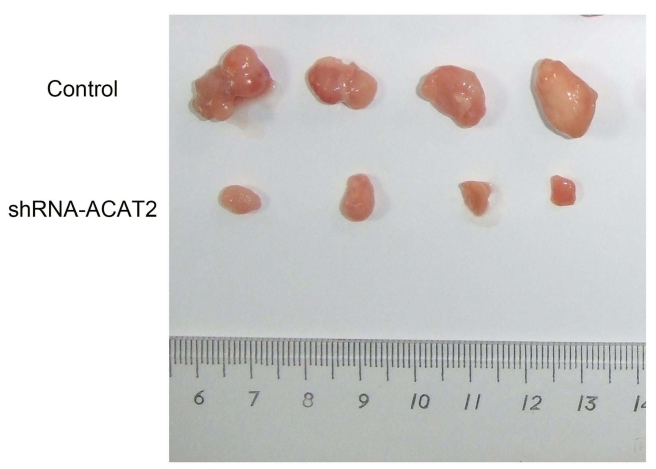

G

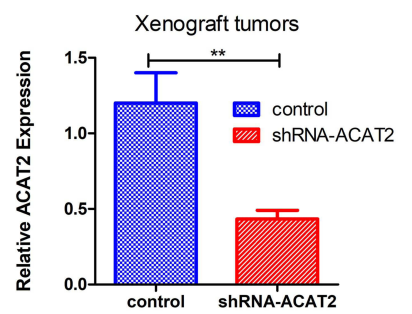

H

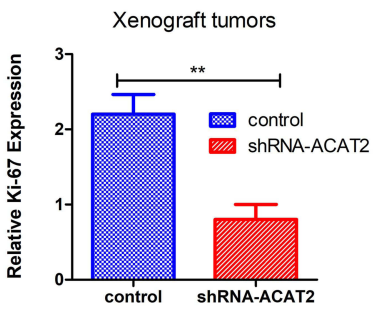

K

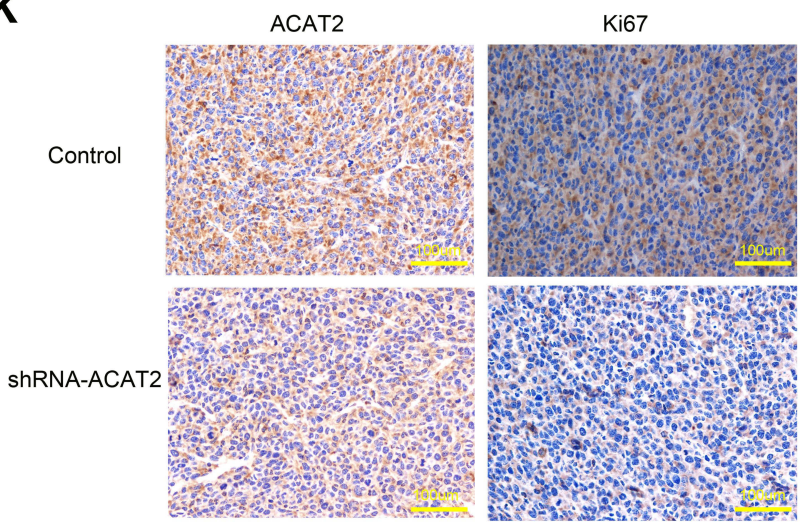

B

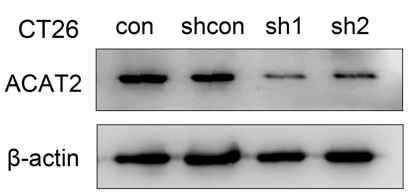

E

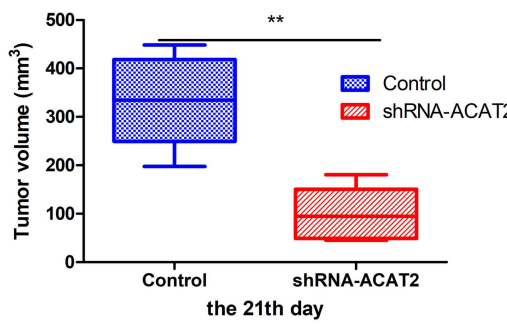

I
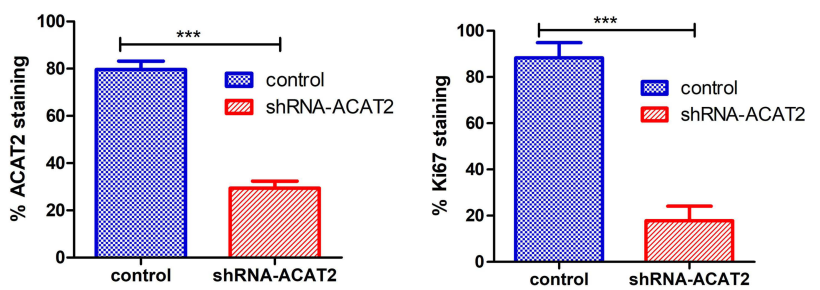

Figure 5 Knockdown of ACAT2 expression suppresses CRC growth and inhibits Ki-67 expression in vivo. (A, B) The efficiency of ACAT2 knockdown in CT26 cells was measured by qPCR and Western blotting. (C, D) CT26 cells or shRNA-ACAT2 CT26 cells were injected into BALB/c mice. Photograph of dissected tumors (upper: control group; lower: shRNA-ACAT2 group; $n=4 ; \mathrm{P}<0.0 \mathrm{I})$. The tumor volumes were measured every 3 days. The shRNA-ACAT2 in CT26 cells attenuated tumor growth in mice. (E, F) Tumor volumes and tumor weights on the 2 I st day $(P<0.0 I)$. $(\mathbf{G}, \mathbf{H})$ The expression of ACAT2 and Ki-67 in tissues was detected by qPCR $(\mathrm{P}<0.0 \mathrm{I})$. $(\mathbf{I}, \mathbf{J})$ The graph shows the quantitative analysis of ACAT2 and Ki67 staining. (K) The protein expression ACAT2 and Ki67 in dissected tumor samples were evaluated by IHC. Scale bar: I00um. (L) Based on TCGA dataset analysis, ACAT2 expression was positively correlated with $\mathrm{Ki}-67$ expression in $\mathrm{CRC}\left(\mathrm{P}=1.3 \times 10^{-7}\right)$. $* * \mathrm{P}<0.0 \mathrm{I}$, $* * * \mathrm{P}<0.00 \mathrm{I}$; compared with the control group. 


\section{Publish your work in this journal}

OncoTargets and Therapy is an international, peer-reviewed, open access journal focusing on the pathological basis of all cancers, potential targets for therapy and treatment protocols employed to improve the management of cancer patients. The journal also focuses on the impact of management programs and new therapeutic

Submit your manuscript here: https://www.dovepress.com/oncotargets-and-therapy-journa agents and protocols on patient perspectives such as quality of life, adherence and satisfaction. The manuscript management system is completely online and includes a very quick and fair peer-review system, which is all easy to use. Visit http://www.dovepress.com/ testimonials.php to read real quotes from published authors. 